\title{
RAMALAN NIAT GELAGAT KEPATUHAN ZAKAT PENDAPATAN GAJI: PERBANDINGAN TEORI TINDAKAN BERALASAN DAN TEORI GELAGAT TERANCANG
}

\author{
ZAINOL BIDIN \\ KAMIL MD. IDRIS \\ UUM College of Business \\ Universiti Utara Malaysia
}

\begin{abstract}
ABSTRAK
Kepatuhan zakat merupakan suatu perkara yang penting dalam meningkatkan kutipan zakat. Faktor niat dianggap sebagai prasyarat terdekat dalam menentukan gelagat kepatuhan seseorang. Bagaimanapun, faktor niat tidak tercetus secara tersendiri kerana ada beberapa faktor lain pula yang berkait rapat dengan ketentuan niat. Justeru, kajian ini membandingkan dua model dalam meramal niat individu: teori tindakan beralasan (TTB) dan teori gelagat terancang (TGT). Sebanyak 250 responden dari organisasi awam dan swasta dianalisis dengan menggunakan pendekatan pemodelan persamaan berstruktur. Keputusan menunjukkan bahawa sikap, norma subjektif, dan kawalan gelagat ditanggap memainkan peranan penting dalam mempengaruhi niat gelagat kepatuhan zakat gaji. Kedua-dua TTB dan TGT meramalkan niat gelagat kepatuhan zakat gaji dengan baik, namun TGT mempunyai kelebihan berbanding TTB apabila kebagusuaian padanan model TGT menunjukkan padanan yang lebih baik berbanding TGT. Di samping itu, keupayaan model TGT dalam meramal niat gelagat menunjukkan peningkatan dalam varian diterang, iaitu 48\%. Implikasi terhadap pembuat dasar dan kajian lanjutan turut dibincangkan.
\end{abstract}

Kata kunci: Sikap; norma subjektif; kawalan gelagat ditanggap; niat; zakat; TTB; TGT.

\section{ABSTRACT}

Purpose - This study applied the theory of reasoned action (TRA) and the theory of planned behaviour in an attempt to predict zakat compliance behaviour. The 
objective of this study was to compare two models in predicting intention: the theory of reasoned action (TRA) and the theory of planned behaviour (TPB).

Design/Methodology/Approach - This study was based on an extensive literature review and data were generated from a sample $250 \mathrm{Muslim}$ individuals. A structural equation modeling containing three constructs from TRA and four constructs from TPB were used for statistical analysis.

Findings - The results suggested that both TRA and TPB predicted zakat compliance intention quite well; however, TPB was shown to have higher predictive power than TRA when the former revealed a better goodness of fit model. Besides, the results also indicated that TPB was a better predictor of behavioural intention with $48 \%$ of variance explained.

Originality/Value - The paper provides the first scientific insight into the relationships between TRA and TPB toward zakah compliance intention in the (1) field of zakah on employment income.

"Keywords - Attitude; Subjective Norm; Perceived Behavioural Control; Intention; Zakat; TRA; TPB.

\section{PENGENALAN}

Zakat merupakan rukun Islam yang ketiga. Kepentingan zakat kepada pembangunan negara dan ummah tidak dapat dinafikan kerana sumber zakat penting bagi jaminan sosial, bagi merapatkan jurang pendapatan antara yang kaya dan yang miskin, bagi keharmonian masyarakat dan ia menjadi asas yang kukuh bagi kekuatan ekonomi masyarakat Islam. Malah, pengagihan dana zakat boleh menjana dan merancakkan kuasa beli masyarakat dan sekaligus dapat meningkatkan produktiviti negara. Sumber zakat datangnya daripada berbagai-bagai punca seperti pendapatan gaji, wang simpanan, perniagaan, ternakan, saham, emas, padi dan sebagainya. Zakat pendapatan gaji merupakan satu sumber zakat yang penting dan ia menyumbang kepada peratusan yang tertinggi berbanding kutipan keseluruhan pungutan zakat (Hairunnizam, Sanep, \& Mohd Ali, 2006). Bagaimanapun, zakat pendapatan gaji masih menjadi isu di negara kita. Fatwa wajib zakat pendapatan gaji telah lama dikeluarkan, bagaimanapun ramai individu Muslim masih tidak mematuhi fatwa wajib zakat gaji ini. Umpamanya, kajian gelagat kepatuhan zakat gaji Kamil (2002) di negeri Kedah mendapati hanya 
sekitar 35\% daripada 353 responden yang layak menunaikan zakat gaji mengeluarkan zakat gaji. Aras kepatuhan yang rendah juga dilaporkan berlaku di negeri Perlis (Kamil, Chek Derashid, \& Engku Ismail, 1997), iaitu hanya 35\% sahaja yang membayar zakat gaji. Begitu juga di Pulau Pinang bilangan pekerja Islam yang membayar zakat gaji hanyalah sekitar 39\% iaitu 18,552 daripada 50,000 orang yang layak mengeluarkan zakat gaji (Anon, 2000).

Fenomena gelagat kepatuhan yang rendah ini boleh diperbaiki sekiranya punca berlakunya ketidakpatuhan dapat diketahui. Sebuah hadis Rasullullah SAW yang bermaksud bahawa "amal perbuatan seseorang itu tergantung pada niatnya dan bagi seseorang apa yang ia niatkan" (Mohd Yusof Abas, 1981). Ajzen dan Fishbein (1980) pula melaporkan punca utama sesuatu gelagat ialah niat. Niat pula dipengaruhi oleh tiga faktor utama, iaitu sikap terhadap gelagat (attitude towards behavior), norma subjektif (subjective norm), dan kawalan gelagat ditanggap (perceived behavioral control) (Ajzen, 1991). Niat adalah fokus utama kajian ini kerana banyak penyelidikan tentang zakat sebelum ini jarang memberi tumpuan pada elemen niat sebagai agen yang boleh mempengaruhi gelagat kepatuhan zakat.

Banyak teori dalam bidang psikologi digunakan bagi meramal gelagat, dan ada antaranya yang sesuai digunakan bagi menyiasat gelagat kepatuhan zakat umpamanya, teori tindakan beralasan (theory of reasoned action) dan teori gelagat terancang (theory of planned behavior). Teori tindakan beralasan (Ajzen \& Fishbein, 1980) dan lanjutan teori tersebut, iaitu teori gelagat terancang (Ajzen, 1991) merupakan teori yang popular yang telah diaplikasi dalam berbagai bentuk gelagat. Bagaimanapun, kajian tentang gelagat kepatuhan zakat yang berasaskan kedua-dua teori tersebut agak sukar ditemui. Namun, kedua-dua teori ini pernah diuji dalam dalam bidang yang seumpama zakat iaitu cukai. Contohnya, Hanno dan Violette (1996) telah menggunakan teori tindakan beralasan, manakala Bobek (1997) mengaplikasi teori gelagat terancang dalam kajiannya tentang cukai. Oleh kerana terhadnya aplikasi teori ini dalam bidang zakat, maka adalah wajar kedua-dua teori ini diuji dalam persekitaran zakat. Justeru, objektif kajian ini adalah untuk menguji keupayaan kedua-dua model teoritikal tersebut dalam meramal dan menerangkan niat gelagat kepatuhan zakat gaji. Di samping itu, kajian ini juga bertujuan untuk membandingkan kedua-dua model tersebut dalam meramal niat individu terhadap kepatuhan zakat gaji. 


\section{SOROTAN LITERATUR}

\section{Teori Tindakan Beralasan (TTB)}

Niat memainkan peranan yang penting dalam menentukan gelagat individu termasuk dalam hal gelagat kepatuhan zakat. Kita seharusnya mendapatkan penjelasan bagaimana niat untuk mematuhi zakat boleh tercetus. Justeru, kajian ini menggunakan Teori Tindakan Beralasan (theory of reasoned action) yang meletakkan keutamaan niat sebagai pencetus gelagat (rujuk Rajah 1). Teori ini kerap digunakan oleh para penyelidik yang lepas bagi meramal gelagat pengguna (Fishbein \& Ajzen, 1975; Ryan, 1982; Hanno \& Violette, 1996; Shimp \& Kavas, 1984). Namun, seperti yang dinyatakan tadi, aplikasi teori ini tentang zakat amat terhad. Teori ini mengandaikan manusia melaksanakan gelagat tentang sesuatu perkara di bawah kawalan mereka sepenuhnya (total volitional control) (Fishbein \& Ajzen, 1975). Teori ini mengusulkan bahawa (1) gelagat individu ditentukan oleh niat gelagat (behavioral intention). Niat gelagat merupakan landasan yang paling tepat bagi meramalkan gelagat (Fishbein \& Ajzen, 1975). Bagi memahami niat gelagat, teori ini mengutarakan elemen sikap terhadap gelagat (attitude towards behavior) dan norma subjektif (subjective norms) yang berperanan penting dalam mempengaruhi niat individu.

"Sikap terhadap gelagat ditakrifkan sebagai "darjah penilaian baik atau Dtidak baik seseorang bagi sesuatu gelagat"1 (Ajzen, 1991, hlmn.188). Kepercayaan yang menggariskan sikap individu dikenali sebagai kepercayaan gelagat. Norma subjektif pula ditakrifkan sebagai "tanggapan terhadap tekanan sosial sama ada untuk melaksanakan "atau tidak melaksanakan gelagat tersebut"2 (Ajzen, 1991, hlmn.188). Kepercayaan yang menggariskan norma subjektif ini dikenali sebagai kepercayaan normatif. Setiap individu yang percaya bahawa sesuatu gelagat akan menghasilkan hasil yang baik akan mempunyai sikap yang baik terhadap gelagat tersebut dan begitulah sebaliknya. Demikian juga halnya jika seseorang percaya bahawa orang yang paling dirujuk (referent group) oleh mereka berasa bahawa mereka patut melaksanakan sesuatu gelagat. Dalam hal ini, mereka akan terpengaruh untuk melaksanakan sesuatu gelagat tersebut disebabkan oleh norma subjektif tadi. Banyak kajian lalu yang menggunakan teori tindakan beralasan dalam berbagaibagai bidang mendapati bahawa norma subjektif memberi kesan terhadap niat (Hanno \& Violette, 1996; Miniard \& Cohen, 1983; Oliver \& Bearden, 1985 Shimp \& Kanvas, 1984). 


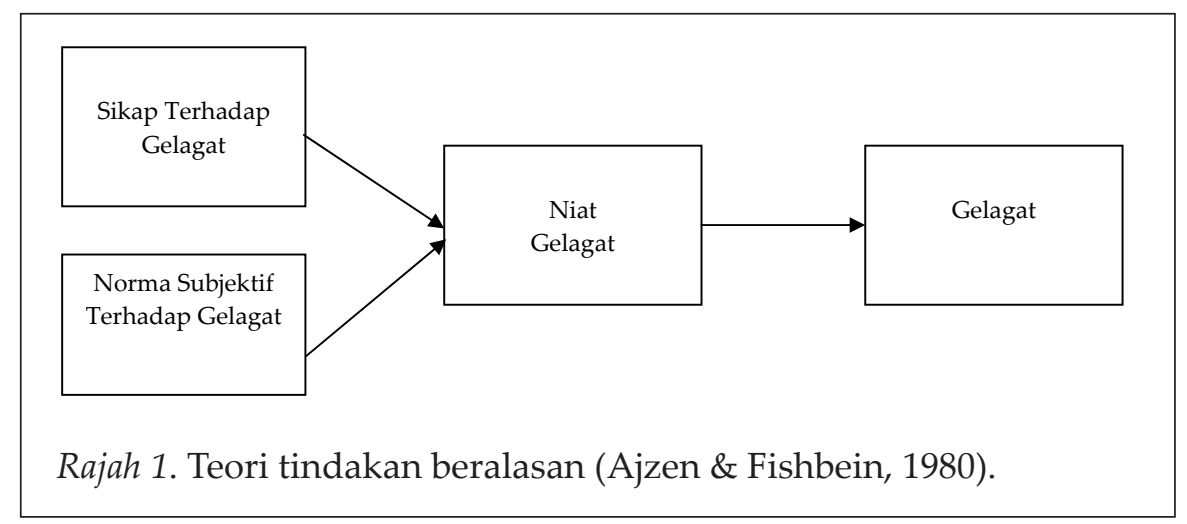

\section{Teori Gelagat Terancang (TGT)}

Teori gelagat terancang (theory of planned behavior) ialah kesinambungan teori tindakan beralasan kerana terdapat satu tambahan konstruk kawalan gelagat ditanggap (perceived behavioral control) yang dimuatkan ke dalamnya. Konstruk kawalan gelagat ditanggap ini diperkenalkan bertujuan bagi menangani keadaan bila mana individu tidak mempunyai kawalan sepenuhnya (incomplete voltional control) terhadap sesuatu gelagat. Teori gelagat terancang ini direka bagi meramal dan menerangkan gelagat manusia dalam gelagat yang spesifik (Ajzen, 1991) (rujuk Rajah 2). Teori ini mencadangkan bahawa niat melaksanakan sesuatu gelagat dipengaruhi oleh sikap terhadap gelagat, norma-norma subjektif, dan kawalan gelagat ditanggap (Ajzen, 1991). Dalam bidang zakat, literatur tentang teori ini agak sukar ditemui. Sebagai suatu model yang umum, maka adalah munasabah jika model ini digunakan bagi menerangkan niat gelagat kepatuhan zakat.

Menurut teori gelagat terancang, kawalan gelagat ditanggap merujuk pada kekangan dalaman dan luaran dalam melaksanakan sesuatu gelagat (Ajzen, 1991). Ianya berperanan sebagai kepercayaan kawalan (control belief) kerana seseorang individu tidak mempunyai sepenuhnya kawalan terhadap faktor dalaman dan luaran. Faktor kawalan dalaman merangkumi aspek kemahiran, keupayaan, maklumat, sumber, dan emosi seperti tekanan dan sebagainya (Ajzen, 1991). Seseorang individu mungkin berniat untuk melaksanakan sesuatu gelagat tetapi tidak melaksanakannya disebabkan kurangnya keupayaan, kekangan luaran atau perkara lain (Trafimow, Sheeran, Conner, \& Finlay, 2002). Bobek dan Hatfield (2003) melaporkan bahawa kepercayaan kawalan merupakan asas penentu kawalan gelagat ditanggap yang merujuk bahawa kepercayaan seseorang individu berkait dengan sumber-sumber atau peluang-peluang yang ada termasuk juga halangan untuk melakukan 
sesuatu gelagat. Jika seseorang berniat melakukan sesuatu gelagat tetapi dihadkan faktor-faktor yang dinyatakan di atas, maka kawalan gelagat ditanggap menjadi salah faktor penting ke atas niat untuk melaksanakan gelagat tersebut.

Para penyelidik sebelum ini melaporkan kawalan gelagat ditanggap berhubungan secara signifikan dengan niat gelagat (Anderson \& Lavallee, 2007; Elliott, Armitage \& Baughan, 2003; Fang \& Shih, 2004; Ingram, Cope, Harju, \& Wuensch, 2000; Rah, Hasler, Painter, \& Chapman-Novakofski, 2004). Menurut Ajzen dan Madden (1986), niat dapat diramal dengan signifikan oleh kawalan kemahuan (volitional control) yang tidak sepenuhnya dan kawalan gelagat ditanggap. Dalam persekitaran percukaian, Bobek dan Hatfield (2003) melaporkan bahawa kawalan gelagat ditanggap mempunyai hubungan yang positif dengan niat kepatuhan cukai. Ajzen dan Driver (1992) mendapati kawalan gelagat ditanggap meningkatkan ramalan ke atas niat untuk melakukan aktiviti-aktiviti rekreasi pada masa lapang. Satu analisis meta (metaanalysis) dilakukan oleh Notani (1998) untuk menguji kesahihan teori gelagat terancang. Beliau mendapati daripada 51 ujian tentang hubungan antara kawalan gelagat ditanggap dengan niat gelagat "sebanyak $42(82.4 \%)$ ujian berhubungan secara signifikan. Sementara itu, daripada 35 ujian tentang hubungan kawalan gelagat ditanggap dengan gelagat hanya 17 (48.6\%) ujian berhubungan secara signifikan. Justeru, rangka kerja teori gelagat terancang dibangunkan adalah bagi memfokus konstruk kawalan gelagat ditanggap sebagai satu peramal niat dan gelagat. Oleh yang demikian, dalam persekitaran zakat yang agak kompleks, dijangkakan bahawa individu pembayar zakat yang Omempunyai kawalan gelagat ditanggap tinggi seharusnya mempunyai niat yang tinggi berbanding mereka yang rendah kawalan gelagat ditanggapnya. Rangka kerja kajian niat gelagat kepatuhan zakat gaji digambarkan seperti dalam Rajah 2.

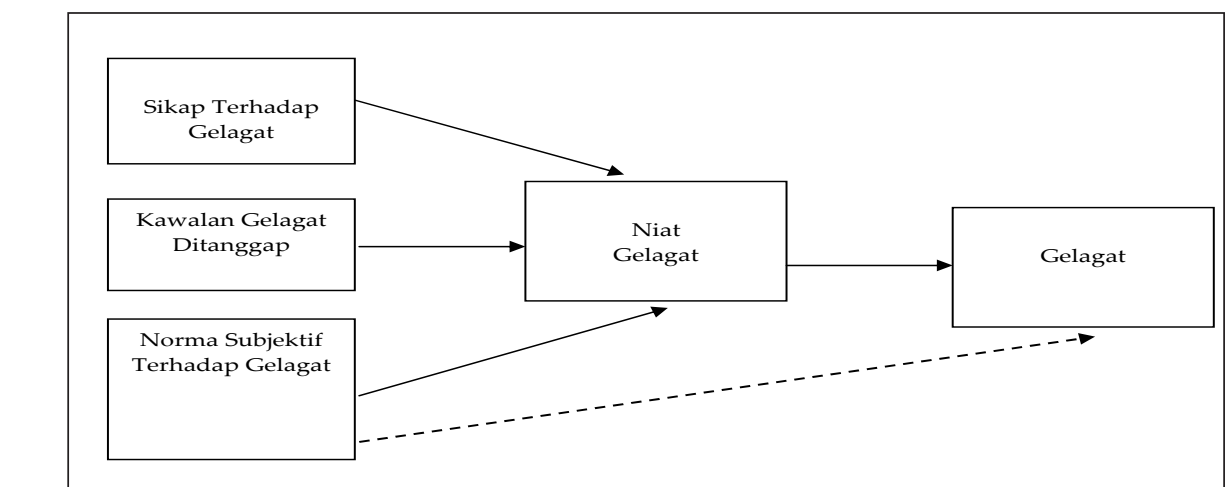

Rajah 2. Teori gelagat terancang (Ajzen, 1991). 


\section{METODOLOGI KAJIAN}

\section{Kutipan Data dan Pensampelan}

Unit analisis bagi kajian ini ialah pekerja Muslim yang berkhidmat di organisasi sektor kerajaan dan swasta di sekitar negeri Kedah. Negeri Kedah dipilih kerana negeri ini telah lama memfatwakan pendapatan gaji sebagai wajib iaitu semenjak tahun 1986 (Kamil, 2002). Rangka pensampelan kajian terdiri daripada individu yang membuat potongan cukai berjadual (PCB) yang terdapat dalam daftar PCB di Lembaga Hasil Dalam Negeri cawangan Kedah. Individu pembayar cukai layak dikenakan zakat pendapatan gaji. Ini kerana had minimum pendapatan kasar yang dikenakan cukai adalah dalam anggaran RM30,000, manakala had pendapatan minimum zakat (nisab) adalah sekitar RM4,464. Terdapat kira-kira 40,000 orang dalam senarai PCB tersebut pada 31 Disember 2005.

Kaedah pensampelan berkelompok (cluster sampling) digunakan dalam kajian ini. Kaedah ini bermula dengan mengenal pasti semua organisasi awam dan swata di negeri Kedah yang mempunyai pekerja yang tertakluk kepada PCB melebihi 20 orang. Ini diikuti dengan persampelan rawak ke atas setiap organisasi berkenaan. Sebanyak 30 organisasi (awam dan swasta) dipilih dan diedarkan soal selidik. Daripada 600 orang yang dihantar soal selidik, sebanyak 312 berjaya dikutip dan 250 daripadanya boleh digunakan bagi tujuan analisis. Saiz sampel yang dianggap sesuai supaya boleh dibuat penyeluruhan (generalization) adalah di antara 15 hingga 20 bagi setiap pemboleh ubah bebas (Hair, Anderson, Tatham, \& Black, 1998).

\section{Pengukuran}

\section{Niat Gelagat Kepatuhan Zakat Gaji}

Seperti yang disarankan oleh Ajzen (1991), niat gelagat diukur melalui persamaan dengan ciri-ciri gelagat seperti tindakan, sasaran, konteks dan masa. Niat gelagat kepatuhan zakat gaji diukur dengan menggunakan skel Likert 5 mata. Dalam kajian ini, soalan-soalan niat gelagat diadaptasikan daripada Zainol dan Kamil (2007) yang mempunyai 3 soalan. Niat bayaran zakat gaji diukur secara berjeda (interval), iaitu mengandungi 3 soalan yang mengandungi kenyataan positif seperti "Saya akan membayar zakat gaji," dan "Saya akan membayar zakat gaji pada tiap-tiap tahun". 


\section{Sikap}

Soalan-soalan yang dikemukakan merupakan pandangan orang ramai tentang fatwa zakat gaji yang telah dibina oleh Kamil (2002) dalam kajian beliau mengenai gelagat kepatuhan zakat gaji. Sebanyak tiga soalan digunakan dalam kajian ini yang terdiri daripada kenyataan positif. Soalan-soalan yang dikemukakan seperti seperti "Saya gembira membayar zakat gaji kerana dapat memenuhi tanggungjawab" dan "Saya yakin bahawa gaji wajib dikeluarkan zakat apabila cukup syaratnya". Kesemua soalan diukur secara berjeda dengan menggunakan skel Likert 5 mata.

\section{Norma Subjektif}

Norma subjektif (kumpulan rujukan) diukur secara berjeda dengan menggunakan skel Likert 5 mata. Kesemuanya diadaptasi daripada instrumen yang digunakan oleh Zainol dan Kamil (2007) yang mempunyai 3 soalan. Kesemua soalan tersebut diukur secara berjeda dan menggunakan skel Likert 5 mata. Antara kenyataan bagi soalansoalan yang diuji tersebut seperti "Ibubapa saya menasihati saya supaya membayar zakat gaji" dan "Ibubapa saya menyokong saya supaya membayar zakat gaji".

\section{Kawalan Gelagat Ditanggap}

Kawalan gelagat ditanggap dalam kajian ini diadaptasikan daripada "kajian Taylor dan Todd (1995). Kawalan gelagat ditanggap merujuk Okepada sejauh manakah kawalan seseorang dari segi kemampuan individu Muslim bagi melaksanakan tanggunjawab membayar zakat hasil daripada pendapatan gaji mereka. Soalan-soalan yang diajukan disesuaikan dengan konteks zakat. Sebanyak tiga soalan diajukan "yang terdiri daripada kenyataan positif. Antara kenyataannya seperti "Saya mampu untuk membayar zakat walaupun terpaksa menghadapi berbagai cabaran". Setiap soalan diukur dengan menggunakan skel Likert 5 mata.

\section{Analisis Data}

Data kajian dianalisis dengan mengaplikasikan pemodelan persamaan berstruktur dengan menggunakan perisian AMOS IV(Arbuckle \& Worthke, 1999). Pendekatan dua langkah (two-step approach) seperti yang dicadangkan oleh Anderson dan Gerbing (1988) diaplikasikan bagi tujuan analisis data. Pertama, pengukuran model (measurement model) melalui analisis faktor pengesahan (confirmatory factor analysis) dengan kaedah pemodelan persamaan berstruktur diperiksa bagi 
mengesahkan (validate) instrumen kajian. Ini diikuti dengan analisis pemodelan persamaan berstruktur bagi meguji hubungan dalam model berstruktur (structural model), iaitu merujuk kepada hubungan pemboleh ubah sikap, norma subjektif, dan kawalan gelagat ditanggap dengan niat gelagat kepatuhan zakat gaji. Pemodelan persamaan berstruktur merupakan satu teknik pengesahan bagi analisis data yang menjadi perhatian oleh para penyelidik pada masa kini (Anderson \& Gerbing, 1988; Hair et al., 1998; Fornell \& Larcker, 1981). Berbagai-bagai indeks kebagusuaian padanan (goodness of fit indices) digunakan bagi menilai padanan model yang dicadangkan dalam kajian dengan data.

Literatur melaporkan terdapat beberapa indeks ukuran padanan yang selalu digunakan sebagai tanda aras dalam menentukan kebagusuaian padanan sesuatu model, antaranya chi-square $\left(\chi^{2}\right)$; root mean-square error of approximation (RMSEA) (Bollen, 1989; Browne \& Cudeck, 1993; Hair et al., 1998; Hu \& Bentler, 1999), tucker-lewis index (TLI) dan normed fit inde) (NFI) (Hair et al., 1998; Hu \& Bentler, 1999), dan comparative fit index CFI) dan normed chi-square ( $\left.\chi^{2} / \mathrm{df}\right)$ (Hair et al., 1998).

Bagimemantapkan kedudukan konstruk dalam kedua-dua teori tersebut, ujian kebolehpercayaan dan kesahan konstruk (construct validity) dilakukan. Kebolehpercayaan konstruk berpandukan kebolehpercayaan komposit (composite reliability). Kesahan konstruk pula melibatkan kesahan memusat (convergent validity) dan kesahan pendiskriminan (discriminant validity). Kesahan memusat dinilai berdasarkan penelitian kepada koefisien setiap item berbeban secara signifikan dan juga purata varians dipetik (average variance extracted) bagi sesuatu pemboleh ubah pendam (latent variable) (Anderson \& Gerbing, 1988; Fornell \& Larcker, 1981). Nilai purata varians dipetik yang melebihi 0.50 menandakan kesahan memusat berada pada posisi yang baik (Fornell \& Larcker, 1981). Sementara itu, kesahan pendiskriminan pula dinilai dengan dibuat perbandingan antara korelasi kuasa dua (squared correlations) antara dua konstruk dengan purata varian dipetik masing-masing. Jika purata varian dipetik melebihi korelasi kuasa dua, maka kesahan pendiskriminan dicapai (Fornell \& Larcker, 1981).

\section{KEPUTUSAN}

\section{Analisis Faktor Pengesahan}

Pengukuran model melalui analisis faktor pengesahan diaplikasikan bagi konstruk sikap, norma subjektif, kawalan gelagat ditanggap, 
dan niat gelagat. Kaedah ini penting bagi memantapkan kedudukan unidimensi, kebolehpercayaan dan kesahan konstruk (Anderson \& Gerbing, 1988). Unidimensi sesuatu faktor dinilai berdasarkan ukuran kebagusuaian padanan (goodness of fit measure) terhadap model yang dicadangkan dalam kajian. Sesuatu model dianggap baik jika kedudukan kebagusuaian padanan bagi nilai indeks NFI, CFI, dan TLI melebihi daripada 0.90 (Hair et al., 1998; Arbuckle, 1999). Sementara itu, nilai $\chi^{2} / \mathrm{df}$ harus kedudukan kurang daripada 2.0, manakala nilai RMSEA tidak melebihi 0.08 (Hair et al., 1998; Arbuckle, 1999).

Rajah 3 memaparkan kedudukan model faktor pengesahan di mana dipaparkan kebagusuaian padanan kepada data, $\chi^{2}=63.509, p=0.066 ; \chi^{2} /$ $\mathrm{df}=1.323 ; \mathrm{NFI}=0.995 ; \mathrm{CFI}=0.999 ; \mathrm{TLI}=0.998 ; \mathrm{RMSEA}=0.036$. Keputusan analisis faktor pengesahan dalam model kajian ini yang terdiri daripada 12 indikator mencapai tahap kebagusuaian padanan yang baik. Seterusnya, kebolehpercayaan diukur dengan menggunakan kaedah kebolehpercayaan komposit. Sesuatu skel adalah boleh dipercayai jika nilai kebolehpercayaan komposit melebihi 0.70 (Anderson \& Gerbing, 1988; Fornell \& Larcker 1981; Hair et al., 1998). Fornell dan Larcker (1981) mengesyorkan supaya nilai kebolehpercayaan komposit yang melebihi 0.70 menandakan tahap kesahan memusat berada pada kedudukan yang baik. Nilai kebolehpercayaan komposit bagi setiap pemboleh ubah pendam (latent variable) dipaparkan dalam Jadual 1. Pemboleh ubah pendam, iaitu norma subjektif, sikap, kawalan gelagat ditanggap, dan niat gelagat masing-masing mempunyai nilai kebolehpercayaan komposit $0.96,0.78,0.89$, dan 0.96 . Nilai purata varians dipetik pula berada pada nilai melebihi 0.50 bagi keempat-empat pemboleh ubah pendam tersebut. Sementara itu, beban faktor terpiawai (standardized factor loading) setiap indikator di bawah setiap pemboleh ubah pendam adalah signifikan. Beban faktor berada pada julat 0.71 hingga 0.98 . Berpandukan pada nilai kebolehpercayaan komposit, purata varians dipetik dan beban faktor di atas, maka kesahan memusat bagi kesemua pemboleh ubah pendam tersebut dicapai (Anderson \& Gerbing, 1988; Fornell \& Larcker, 1981; Hair et al., 1998). Bagi kesahan pendiskriminan pula, perbandingan korelasi kuasa dua (squared correlations) di antara pemboleh ubah dengan purata varians dipetik memaparkan purata varians dipetik melebihi korelasi kuasa dua. Kedudukan purata varians dipetik dan korelasi kuasa dua ditunjukkan dalam Jadual 1 dan Jadual 2. Ini menunjukkan bahawa kesahan pendiskriminan telah dicapai (Anderson \& Gerbing, 1988; Fornell \& Larcker, 1981). 


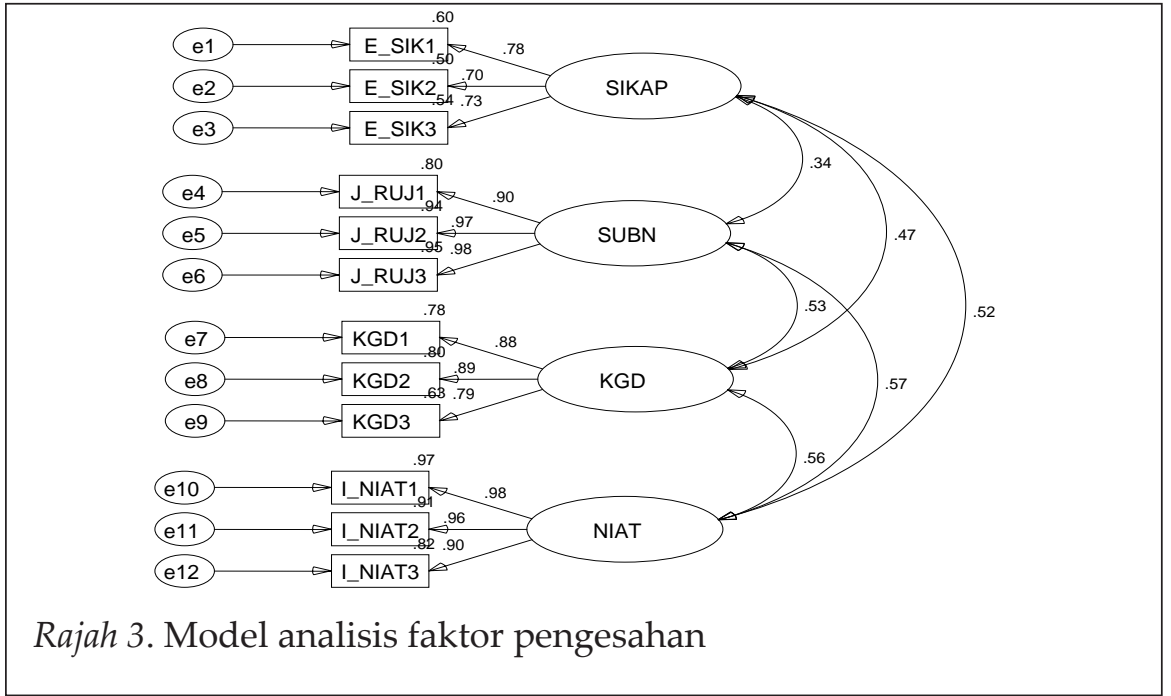

Jadual 1

Beban Faktor Pengesahan Terpiawai

\begin{tabular}{lccc}
\hline Pemboleh ubah & $\begin{array}{c}\text { Kebolehpercayaan } \\
\text { komposit }\end{array}$ & $\begin{array}{c}\text { Purata varians } \\
\text { dipetik }\end{array}$ & Beban faktor \\
Pendam & .96 & .90 & .90 \\
\hline Norma subjektif & & .97 \\
RUJ1 & .78 & .54 & .98 \\
RUJ2 & & & .78 \\
RUJ3 & & .70 \\
Sikap & .89 & .73 & .73 \\
SIK1 & & & .88 \\
SIK2 & & .89 \\
SIK3 & & .90 & .79 \\
Kawalan Gelagat & & & .98 \\
$\quad$ Ditanggap & .96 & .90 \\
KGD1 & & & \\
KGD2 & & & \\
KGD3 & & & \\
Behavioral intention & & & .98 \\
NIAT1 & & & \\
NIAT2 & & & \\
NIAT3 & & & \\
\hline
\end{tabular}

Nota. a semua beban faktor adalah signifikan pada $\mathrm{p}=0.01$. 
Jadual 2

Korelasi antara Pemboleh Ubah Pendam bagi Analisis Faktor Pengesahan

\begin{tabular}{lcccc}
\hline Pemboleh ubah pendam & 1 & 2 & 3 & 4 \\
\hline 1. Norma subjektif & - & & & \\
2. Sikap & $.34(.12)$ & - & & \\
3. Kawalan gelagat ditanggap & $.53(.28)$ & $.47(.22)$ & - & \\
4. Niat & $.57(.32)$ & $.52(.27)$ & $.56(.31)$ & - \\
\hline
\end{tabular}

Nota. a semua beban faktor adalah signifikan pada $\mathrm{p}=0.01$. Nilai dalam kurungan adalah korelasi kuasa dua.

\section{Model Berstruktur}

Analisis model berstruktur (structural model) melalui pemodelan (1) persamaan berstruktur hanya melibatkan hubungan antara pemboleh „ubah pendam. Rajah 4 dan Rajah 5 masing-masing menunjukkan model niat gelagat kepatuhan zakat gaji yang berasaskan TTB dan TGT yang dispesifikasikan dalam kajian ini. Keputusan bagi padanan statistik (fit stastistic) bagi kedua-dua model dipaparkan dalam Jadual 3. Keseluruhan bagi model TTB yang dicadangkan (Rajah 4 dan Jadual 3) menunjukkan kebagusuaian padanan yang baik kepada data, $\chi^{2=} 41.816, \mathrm{p}=0.014 ; \chi^{2} / \mathrm{df}$ $=1.742 ; \mathrm{NFI}=0.996: \mathrm{CFI}=0.998 ; \mathrm{TLI}=0.997 ; \mathrm{RMSEA}=0.055$. Walaupun nilai $\chi^{2}$ masih signifikan, namun indeks-indeks yang lain menunjukkan nilai yang baik seperti mana yang disarankan oleh literatur. Umumnya, $\chi^{2}$ agak sensitif kepada saiz sampel, bilangan indikator, dan model yang kompleks (Hair et al., 1998). Seperti yang ditunjukkan dalam Jadual 4, koefisien lintasan (path coefficient) bagi norma subjektif (0.43) "dan sikap (0.38) dengan niat gelagat masing-masing berhubungan secara signifikan. Norma subjektif merupakan pemboleh ubah yang paling kuat mempengaruhi niat gelagat kepatuhan zakat gaji. Model TTB ini (Rajah 4) dapat menerangkan sebanyak $44 \%$ varians niat gelagat kepatuhan zakat gaji.

Model TGT pula menunjukkan keputusan yang lebih baik berbanding dengan model TRA dari aspek kebagusuaian padanan model (Rajah 5 dan Jadual 3). Kedudukan indeks padanan bagi model TGT adalah nilai $\chi^{2}=63.509, \mathrm{p}=0.066 ; \chi^{2} / \mathrm{df}=1.323 ; \mathrm{NFI}=0.995$ : $\mathrm{CFI}=0.999 ; \mathrm{TLI}=$ 0.998; RMSEA $=0.036$. Model TGT ini berkedudukan yang lebih baik berbanding dengan model TTB. Ini ditunjukkan nilai $\chi^{2}$ yang tidak signifikan, $\chi^{2} / \mathrm{df}$ dan RMSEA yang rendah. Kedudukan indeksi NFI, CFI, dan TLI bagi kedua dua model tidak banyak berubah. 
Jadual 4 menunjukkan koefisien lintasan bagi norma subjektif (0.34), sikap (0.28), dan kawalan gelagat ditanggap (0.25) dengan niat gelagat masing-masing berkait secara signifikan dengan niat gelagat. Norma subjektif juga merupakan pemboleh ubah yang terkuat mempengaruhi niat gelagat kepatuhan zakat gaji. Model TGT ini dapat menerangkan lebih varians dalam niat gelagat kepatuhan zakat gaji, iaitu sebanyak $48 \%$ (rujuk Rajah 5).

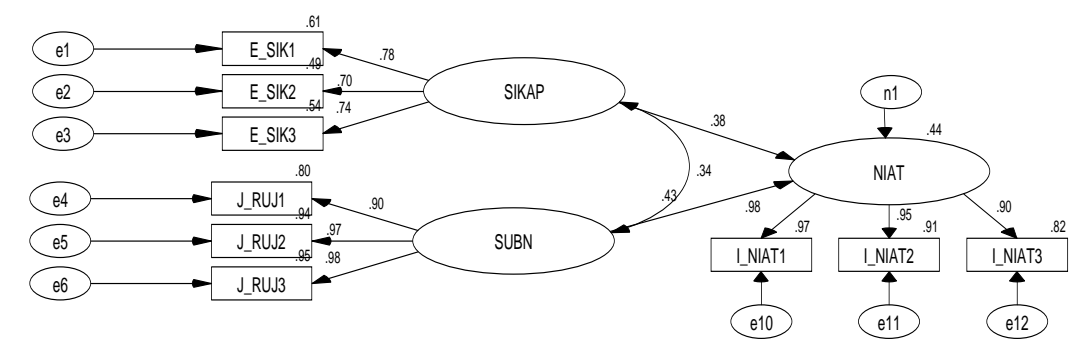

Rajah 4. Model teori tindakan beralasan.

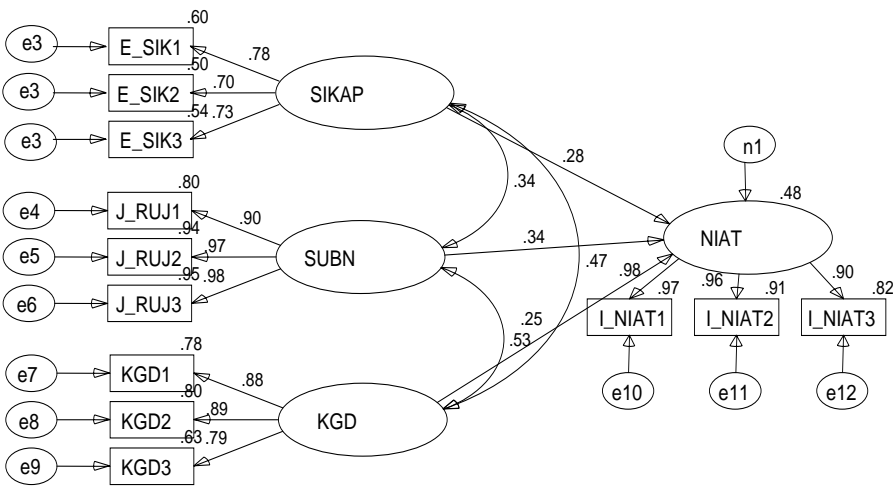

Rajah 5. Model teori tindakan beralasan. 
Jadual 3

Indeks Kebagusuaian Padanan Model Bagi Model TTB dan TGT

\begin{tabular}{lccccccc}
\hline Model & $\chi^{2}$ & $\mathrm{P}$ & $\chi 2 / \mathrm{df}$ & $\mathrm{NFI}$ & $\mathrm{CFI}$ & $\mathrm{TLI}$ & RMSEA \\
\hline Model 1- TTB & 41.819 & 0.014 & 1.742 & .996 & .998 & .997 & .055 \\
Model 2- TGT & 63.509 & 0.066 & 1.323 & .995 & .999 & .998 & .036 \\
\hline
\end{tabular}

Nota. $\mathrm{NFI}=$ normed fit index; $\mathrm{CFI}=$ comparative fit index; TLI= tucker-lewis index; RMSEA; root mean square error of approximation.

Jadual 4

-Lintasan koefisien terpiawai bagi Model TTB dan TGT

\begin{tabular}{lcc}
\hline Lintasan & Koefisien (TTB) & Koefisien (TGT) \\
\hline NS - NG & $0.433^{*}$ & $0.337^{*}$ \\
SIK - NG & $0.380^{*}$ & $0.282^{*}$ \\
KGD - NG & & $0.251^{*}$ \\
\hline
\end{tabular}

Nota. SIK = Sikap, NG = Niat gelagat, $\mathrm{NS}=$ Norma subjektif, $\mathrm{KGD}=$ Kawalan gelagat ditanggap. * $\mathrm{p}<0.01$.

\section{PERBINCANGAN}

Objektif utama dalam kajian ini adalah untuk menyiasat kemampuan kedua-dua teori tindakan beralasan dan teori gelagat terancang bagi meramal niat gelagat kepatuhan bagi zakat pendapatan gaji. -Kajian ini juga menilai perbandingan bagi kedua-dua teori tersebut. Keputusan kajian mempunyai beberapa implikasi dalam persekitaran zakat. Keputusan kajian memaparkan teori gelagat terancang adalah lebih baik berbanding teori tindakan beralasan dalam meramalkan niat gelagat kepatuhan zakat gaji. Dari segi kebagusuaian padanan model, indeks pengukuran model teori gelagat terancang memaparkan keputusan yang lebih baik di mana nilai $\chi^{2}=63.509, \mathrm{p}=0.066 ; \chi^{2} / \mathrm{df}=$ 1.323; $\mathrm{NFI}=0.995$ : $\mathrm{CFI}=0.999 ; \mathrm{TLI}=0.998 ; \mathrm{RMSEA}=0.036$. Tambahan pula, kuasa meramal teori tersebut terhadap niat gelagat kepatuhan zakat pendapatan gaji meningkat kepada $48 \%$ bagi varians diterang. Keputusan ini selari dengan dapatan yang terdahulu yang dibuat dalam persekitaran lain seperti percukaian (Bobek, 1997), teknologi maklumat (Taylor \& Todd, 1995) dan latihan (Anderson \& Lavallee, 2007). Ini merupakan cubaan pertama dalam persekitaran zakat, iaitu dengan membandingkan kedua-dua teori tersebut dalam meramalkan niat 
gelagat. Ini mengesahkan bahawa kedua-dua teori tersebut juga boleh diaplikasikan dalam persekitaran zakat. Ini menandakan kedua-dua teori merupakan teori yang mantap dan boleh digunakan sebagai asas dalam kajian gelagat kepatuhan pada masa hadapan.

Hasil kajian ini juga konsisten dengan laporan terdahulu dalam berbagai-bagai bidang kajian yang mendapati kedua-dua pemboleh ubah dalam teori tindakan beralasan tersebut mempunyai hubungan yang signifikan dengan niat (Hanno \& Violette,1996; Oliver \& Bearden, 1985; Shimp \& Kavas, 1984; Zainol \& Kamil, 2007). Dapatan kajian ini juga selari dengan dapatan kajian lalu yang menunjukkan bahawa ketiga-tiga pemboleh ubah berkaitan secara signfikan dengan niat apabila teori gelagat terancang digunakan (Hagger \& Chatzisarantis, 2005; Taylor \& Todd, 1995; Rah et al., 2004). Keputusan kajian ini seterusnya menyokong dapatan Ajzen (1991) yang menyemak 16 kajian lampau bahawa penambahan pemboleh ubah kawalan gelagat ditanggap (menggunakan teori gelagat terancang) dapat meningkatkan ramalan dalam niat. Justeru, ketiga-tiga pemboleh ubah ini perlu diberi perhatian oleh pihak berkuasa zakat atau Baitulmal demi meningkatkan tahap kepatuhan zakat dengan berpandukan niat gelagat kepatuhan yang merupakan fokus utama kajian ini. Ini kerana niat merupakan ramalan bagi gelagat sebenar pembayar zakat di masa depan.

Persekitaran zakat sama juga seperti persekitaran cukai yang agak kompleks di mana selain daripada faktor individu, faktor persekitaran juga jelas memainkan peranan penting dalam mempengaruhi gelagat individu. Bagi melaksanakan tanggungjawab berzakat, pembayar zakat tidak mempunyai kawalan yang sepenuhnya di mana kemampuan dan sumber-sumber yang ada pada pembayar zakat haruslah ada sebelum mematuhinya. Tanpanya, niat pembayar zakat bagi membayar zakat akan menjadi rendah. Oleh itu, bagi meningkatkan niat gelagat dan seterusnya gelagat kepatuhan zakat gaji, pihak berkuasa zakat harus melihat aspek kawalan gelagat ditanggap yang ada pada pembayar zakat. Sebagai contoh, pihak berkuasa zakat boleh mengambil langkah menyediakan kemudahan potongan zakat berjadual di setiap organisasi seperti mana yang dibuat oleh Lembaga Hasil Dalam Negeri melalui potongan cukai berjadual. Ini dapat diberi pilihan serta meringankan beban kewangan pembayar zakat jika dibayar sekaligus. Di samping itu, pembayaran melalui talian terus (on line) juga harus diperkenalkan demi memudahkan pembayar zakat menunaikan zakat tanpa perlu ke pejabat zakat.

Walaupun kajian ini mendapati norma subjektif, sikap dan kawalan gelagat ditanggap adalah pemboleh ubah yang penting dalam 
meramalkan niat gelagat kepatuhan, namun hubungan yang diperolehi adalah berkaitan secara langsung (direct effect) dengan niat gelagat. Bagaimanapun, gelagat manusia adalah kompleks dan ditambah dengan persekitaran zakat yang agak kompleks, maka dijangkakan hubungan secara tidak langsung (indirect effect) akan memberi kesan yang penting terhadap niat gelagat pembayar zakat. Ini kerana kajian lampau menunjukkan bahawa hubungan pemboleh ubah norma subjektif, sikap dan kawalan gelagat ditanggap saling bergantungan dan memberi keputusan yang berbeza (Shimp \& Kanvas, 1984; Oliver \& Bearden, 1985).

\section{RUMUSAN}

Kajian ini cuba menilai keupayaan teori tindakan beralasan dan teori gelagat terancang terhadap niat gelagat kepatuhan dalam persekitaran zakat. Keputusan kajian menunjukkan teori tindakan beralasan dan teori gelagat terancang boleh diaplikasikan dengan baik dalam meramal "niat gelagat kepatuhan zakat gaji. Ketiga-tiga pemboleh iaitu, norma subjektif, sikap dan kawalan gelagat ditanggap menunjukkan pengaruh yang positif dan signifikan terhadap niat gelagat individu pembayar zakat. Bagaimanapun, kedudukan kebagusuaian padanan model bagi teori gelagat terancang adalah lebih baik serta dapat meningkatkan kuasa meramal niat gelagat kepatuhan zakat gaji. Justeru, kajian pada masa depan dicadangkan supaya mempertimbangkan pengaruh norma subjektif, sikap dan kawalan gelagat ditanggap.

\section{NOTA AKHIR}

The degree to which a person has a favorable or unfavorable evaluation or appraisal of the behavior in question.

2. Perceived social pressure to perform or not to perform the behavior.

\section{RUJUKAN}

Anon. (2000). 50,000 pekerja Islam dikesan layak bayar zakat. (2000, Sept. 15). Utusan Malaysia, Utara, Sept. 15. hlm.25.

Ajzen, I. (1991). The theory of planned behavior. Organizational Behavior and Human Decision Processes, 50, 179-211. 
Ajzen, I., \& Driver, B.L. (1992). Application of the theory of planned behavior to leisure choice. Journal of Leisure Research, 24(3), 207-224. Ajzen, I., \& Fishbein, M. (1980). Understanding attitudes and predicting social behavior, Englewood Cliffs, NJ: Prentice-Hall.

Ajzen, I., \& Madden, T.J. (1986). Prediction of goal directed behavior: Attitudes, intentions, and perceived behavioural control. Journal of Experimental Social Psychology, 22, 453-474.

Anderson, A.G., \& Lavallee, D. (2007, in press). Applying the theories of reasoned action and planned behavior to athlete training adherence behavior. Applied Psychology: An International Review.

Anderson, J., \& Gerbing, D. (1988). Structural equation modeling in practice: A review and recommended two-step approach. Psychological Bulletin, 103(3), 411-423.

Arbuckle, J.L., \& Wothke, W. (1999). AMOS users' guide version 4.0, Chicago, IL: Smallwaters Corporation.

Bobek, D. D. (1997). Tax fairness: How do individuals judges fairness and what effects does it have on their behavior. (Ph.D. Dissertation). University of Florida, Gainesville.

Bobek, D.D., \& Hatfield, R.C. (2003). An investigation of the theory of planned behavior and the role of moral obligation in tax compliance. Behavioral Research in Accounting, 15, 13-38.

Browne, M.W., \& Cudeck, R. (1993). Alternative ways of assessing model fit, in Testing structural equation models. K.A. Bollen and J.S. Long, (Eds.) Newbury Park, CA: Sage, 136-62.

Elliott, M. A, Armitage, C. J., \& Baughan, C. J. (2003). Driver's compliance with speed limits: an application of the theory of planned behavior. Journal of Applied Psychology, 88(5), 964-972.

Fang, K., \& Shih, Y. (2004). The use of a decomposed theory of planned behavior to study internet banking in Taiwan. Internet Research, 14(3), 213-223.

Fishbein, M., \& Ajzen, I. (1975). Belief, attitude, intention, and behaviour: An introduction to theory and research, Reading, MA: Addison-Wesley.

Fornell, C., \& Larcker, D. (1981). Evaluating structural equation models with unobserved variable and measurement error. Journal of Marketing Research, 18, 39-50.

Hair, J. F., Anderson, R. E., Tatham, R. L., \& Black, W. C. (1998). Multivariate data analysis. New Jersey: Prentice Hall.

Hairunnizam Wahid, Sanep Ahmad \& Mohd Ali Mohd Noor. (2006). Kesedaran membayar zakat pendapatan di Malaysia. Laporan tidak diterbitkan. Pusat Pengajian Ekonomi, Fakulti Ekonomi \& Perniagaan, Universiti Kebangsaan Malaysia. 
Hagger, M.S., \& Chatzisarantis, N.L.D. (2005). First and higher-order models of attitudes, normative influence, and perceived behavioral control in the theory of planned behaviour, Bristish Journal of Social Psychology, 44, 513-535.

Hanno, D., \& Violette, G.R. (1996). An analysis of moral and social influences on taxpayer behavior. Behavioral Research in Accounting, $8,57-75$.

Hu, L., \& Bentler, P. M. (1999). Cut off criteria for fit indexes in covariance structure analysis: Conventional criteria versus new alternatives. Structural Equation Modeling, 6(1), 1-55.

Ingram, K. L., Cope, J. G., Harju, B. L., \& Wuensch, K. L. (2000). Applying to graduate school: A test of the theory of planned behavior. Journal of Social Behavior and Personality, 15(2), 215-226.

Kamil Md Idris. (2002). Gelagat kepatuhan zakat gaji di kalangan kakitangan awam. (Tesis Ph.D tidak diterbitkan). Universiti Utara Malaysia, Malaysia.

Kamil Md Idris, Chek Derashid, \& Engku Ismail Engku Ali. (1997, Nov.). Zakat penggajian: Suatu tinjauan terhadap pengetahuan dan amalan Muslimin negeri Perlis, Kertas kerja dibentangkan di Seminar Penyelidikan Universiti Utara Malaysia, Sintok, Kedah.

Miniard, P. W., \& Cohen, J. B. (1983). Modeling personal and normative influences on behavior. Journal of Consumer Research, 10, 169-180.

Oliver, R.L., \& Bearden, W.O. (1985). Crossover effects in the theory of reasoned action: A moderating influence attempt. Journal of Consumer Research, 12, 324-340.

Mohd Yusof Abas. (1981). 40 hadith pilihan. Kuala Lumpur: Yayasan Dakwah Islamiah Malaysia.

Notani, A.S. (1998). Moderators of perceived behavioral control's predictiveness in the theory of planned behavior: A meta-analysis. Journal of Consumer Psychology, 7(3), 247-271.

Rah, J.H., Hasler, C.M., Painter, J.E., \& Chapman-Novakofski, K. M. (2004). Applying the theory of planned behavior to women's behavioral attitudes on and consumption of soy products. Journal of Nutrition Education Behavior, 36, 238-244.

Ryan, M. J. (1982). Behavioural intention formation: The interdependency of attitudinal and social influence variables. Journal of Consumer Research, 9, 263-278.

Shimp, T. A., \& Kavas, A. (1984). The theory of reasoned action applied to coupon usage. Journal of Consumer Research, 11, 795-809.

Taylor, S., \& Todd, P. (1995). Decomposition and crossover effects in the theory of planned behavior: A study of consumer adoption intentions. International Journal of Research in Marketing, 12, 137-55. 
Trafimow, D., Sheeran, P., Conner, M., \& Finlay, K.A. (2002). Evidence that perceived behavioral control is a multidimensional construct: Perceived control and perceived difficulty. British Journal of Social Psychological, 41, 101-121.

Zainol Bidin, \& Kamil Md Idris. (2007). The role of attitude and subjective norm on intention to comply zakat on employment income. IKaZ International Journal of Zakat, 1(1). 